Maurer School of Law: Indiana University

Digital Repository @ Maurer Law

\title{
The Significance of National Wildlife Refuges in the Development of U.S. Conservation Policy
}

Robert L. Fischman

Indiana University Maurer School of Law, rfischma@indiana.edu

Follow this and additional works at: https://www.repository.law.indiana.edu/facpub

Part of the Environmental Law Commons, and the Natural Resources Law Commons

\section{Recommended Citation}

Fischman, Robert L., "The Significance of National Wildlife Refuges in the Development of U.S.

Conservation Policy" (2005). Articles by Maurer Faculty. 218.

https://www.repository.law.indiana.edu/facpub/218

This Article is brought to you for free and open access by the Faculty Scholarship at Digital Repository @ Maurer Law. It has been accepted for inclusion in Articles by Maurer Faculty by an authorized administrator of Digital Repository @ Maurer Law. For more information, please contact rvaughan@indiana.edu. 


\title{
The SigNifiCANCE OF NATIONAL WiLDLIFE REFUGES IN THE DEVELOPMENT OF U.S. CONSERVATION POLICY
}

\author{
ROBERT L. FISCHMAN* \\ Table of Contents
}

I. INTRODUCTION.................................................. 1

II. AN OVERVIEW OF THE REFUGE SYSTEM....................... 3

III. THE SUPERSTAR REFUGE: ARCTIC................................ 6

IV. THE FIRST REFUGE: THE PELICAN ISLAND SANCTUARY. 9

V. GROWTH AND CONSOLIDATION: ENCLAVES TO FLYWAYS 11

VI. The RECEnT ERA: Ecosystem MAnAGEMENT................. 15

VII. CONCLUSION............................................................. 20

\section{INTRODUCTION}

The National Wildlife Refuge System has begun its second century amidst conflict over oil development in the Arctic and concern over the ecological sustainability of uses throughout its nearly 550 individual refuges. ${ }^{1}$ The face of the future is uncertainty. However, a retrospective review of refuge conservation shows a promising trajectory. The system has overcome persistent neglect to contribute to conservation policy. Haltingly, it has kept pace with conservation science to remain the chief American contribution to large-scale wildlife protection. Early on, it pioneered the use of habitat acquisition to protect imperiled species. More recently, it has begun to implement the cutting-edge ecological mandate to maintain biological integrity, diversity, and environmental health. Perhaps the most meaningful feature of the history of the refuge system is how closely it mirrors the development of conservation policy in the twentieth century.

Nonetheless, with the exception of the Arctic National Wildlife Refuge, the system has largely ducked the national

\footnotetext{
* Professor of Law, Indiana University - Bloomington; J.D., M.S. University of Michigan, A.B. Princeton University. This article was presented as the Spring 2005 Distinguished Lecture in Environmental Law at the Florida State University College of Law on April 4, 2005. I owe thanks to Associate Dean J.B. Ruhl of the FSU College of Law, and the editors of this Journal, for the opportunity to present this paper as the Distinguished Lecturer. I am also grateful for the excellent research assistance of Tammy Mitchell.

1 The National Wildlife Refuge System includes 545 refuges, on approximately 100 million acres. U.S FISH \& WILDLIFE SERVICE, ANNUAL REPORT OF LANDS UNDER CONTROL OF THE U.S. Fish \& WildLIFE SERVICE AS OF SEPTEMBER 30, 2004 at 1 (Apr. 2005) [hereinafter FWS LAND REPORT], http://www.fws.gov/realty/PDF_Files/2004_lands.pdf.
} 
spotlight. The refuges have sidestepped the dramatic controversies that have dogged other land systems: logging and road-building in the national forests, ${ }^{2}$ grazing on Bureau of Land Management tracts, ${ }^{3}$ and motorized vehicle (including snowmobile and jet ski) use in national parks. ${ }^{4}$

Unlike the National Park System, the refuge system contains few of the signal icons of our natural heritage. It lacks the mammoth scale of the Bureau of Land Management System. No popular mascot like Smokey Bear represents the refuge system. The refuges are the under-appreciated, quiet, middle child in the family of federal public lands. They receive the fewest visitors and the smallest per acre appropriations. ${ }^{5}$ Neither the oldest nor the youngest, the largest nor the smallest, the most protected nor the least restricted, the refuge system has languished at the periphery of public consciousness and legal scrutiny of public lands. But, like the tree whose rings record changes in the weather over the course of its life, the refuge system encapsulates within its geography, management, and law a history of American conservation policy of the last hundred years.

This article tells the story of the refuges and along the way highlights how the refuge system is emblematic of the larger epic of nature conservation in the United States. The tale focuses on two refuges that, at first blush, seem extremely different. Pelican Island is a speck of land in a Florida lagoon, surrounded by

\footnotetext{
2 See Laura Paskus, Feds Pass Roadless Headache to States, High CounTRY News, Aug. 16, 2004, http://www.hcn.org/servlets/hcn.Article?article_id=14926; Blaine Harden, Reopening Forest Areas Stirs Debate in Alaska; Many Question the Need to Aid Timber Industry, The Washington Post, Aug. 1, 2004, at A3; Kathie Durbin, In Fire's Aftermath, Salvage Logging Makes a Comeback, High CounTry News, Sept. 1, 2003, http://www.hcn.org/servlets/hcn.Article?article_id=14197.

3 Juliet Eilperin, In Grazing Debate, Some Ranchers Are Switching Sides, THE Washington Post, Sept. 13, 2004, at A2; April Reese, At 40, Landmark Law Protecting America's Wild Lands Tested in New Ways, LAND LETTER, Sept. 2, 2004; Faith Bremner, Changes to Grazing Regulations Cause Controversy, GANNETT NEWs SERVICE, Feb. 27, 2004.

${ }^{4}$ Cornelia Dean, Park Service under Attack by Adviser, N.Y. TIMES, Oct. 29, 2004, at A16; Felicity Barringer, Judge's Ruling on Yellowstone Keeps It Open to Snowmobiles, N.Y. TIMES, Oct. 16, 2004, at A9; Katharine Q. Seelye, Lawsuit in Texas Challenges Ban on Personal Watercraft in National Parks, N.Y. TimeS, Apr. 15, 2002, at A18.

${ }_{5}^{5}$ Cam Tredennick, The National Wildlife System Improvement Act of 1997: Defining the National Wildlife Refuge System for the Twenty-First Century, 12 ForDHAM ENVTL. L.J. 6465 (2000) (citing H.R. Rep. No. 105-329, at 4 (1997)) (showing that the Refuge System received smaller appropriations per acre managed than any other major federal public land system). During fiscal year 2003 the Refuge System hosted 39 million visits, compared to the National Park Service's 266 million visits and the Bureau of Land Management's 66.6 million visits. U.S. DEP'T OF THE INTERIOR, ORIENTATION TO THE U.S. DEP'T OF THE INTERIOR, ORIENTATION WEBSITE DATA TABLES (2004), http:// www.doiu.nbc.gov/orientation/ tables_all.cfm. The U.S. Forest Service hosted 212 million visits in 2003. U.S. DEPT. OF Agriculture, Forest Service Performance AND Accountability Report - Fiscal YEAR 2003 at 10 (Apr. 2004), http://www.fs.fed.us/plan/par/2003/final/pdf/ForestService 2003PerfAcctReport.pdf.
} 
residential and commercial development. ${ }^{6}$ The Arctic National Wildlife Refuge is at the other end of the country, on the coast of the Arctic Ocean. It is enormous, 19.3 million acres (including 8 million acres of wilderness), and encompasses a range of ecosystems from frigid mountain peaks to the coastal tundra. ${ }^{7}$ Yet, both played key roles in the development of the refuge system, and both are typical refuges in providing significant wetlands habitat for migratory animals.

I begin with an overview of the refuge system, then talk about these two prominent refuges. From there, I review the evolution of refuge system management and show how it reflects the major conservation developments over the past century. I conclude by observing the ways in which the national wildlife refuges are now the most important federal lands for demonstrating sustainability and ecosystem management on a large scale.

\section{AN OVERVIEW OF THE REFUGE SYSTEM}

The National Wildlife Refuge System is a tangle of some 550 land units with widely varying sizes, purposes, origins, climates, levels of development and use, and degrees of federal ownership. This is due to the opportunistic growth of wildlife refuges, migratory bird refuges, waterfowl production areas, game ranges, wildlife management areas, and other land unit categories into the system. ${ }^{8}$ Units were created in response to crises, personal preferences of high-ranking officials (and legislators), funding availability, social program priorities, donations, and, of course, wildlife needs. The retrospective task of bringing coherence to this conglomeration requires historical context, flexible interpretation, and a modicum of imagination. Despite the diverse authorities and origins of the individual wildlife refuges, all share a general purpose of animal conservation. All refuges are managed by the U.S. Fish and Wildlife Service ("Service" or "FWS").

\footnotetext{
${ }^{6}$ Pelican Island National Wildlife Refuge, http://www.fws.gov/pelicanisland/; Anne Criss, Refuges at Risk, 21 NAT'L WETLANDS NEWSL. (Envtl. Law Inst.), July-Aug. 1999, at 1, 12.

${ }^{7}$ Arctic National Wildlife Refuge, http://arctic.fws.gov.

8 ADVISORY COMM. ON WILDLIFE MANAGEMENT, appointed by Interior Sec. Stewart L. Udall, REPORT ON THE NATIONAL WILDLIFE REFUGE SYSTEM (1968), reprinted in U.S. FiSH AND Wildlife, Final EnVIronmental Statement, OpERATion of the NATional WiLdLIFE REFUGE SYSTEM app. W, at W-1 (1979). Beginning in 1940, there has been an ongoing effort to consolidate the refuge unit types into fewer categories. Proclamation No. 2416, 54 Stat. 2717 (July 25, 1940).
} 
The most significant physical attributes of the sprawling, 95 million acre refuge system are its broad reach and diverse landscapes. ${ }^{9}$ Therefore, the system is a key network for protecting representative ecosystems and sustaining migrating animals, such as ducks and caribou.

As with the National Park System, the bulk of the refuge system lands and its largest units occur in Alaska. ${ }^{10}$ Though 96 percent of refuge units are located outside of Alaska, they constitute only 15 percent of the system's acreage. The Arctic National Wildlife Refuge tops the list of giant refuges with 19.3 million acres. Yukon Delta National Wildlife Refuge runs a close second with 19.2 million acres. The 3.5 million acre Alaska Maritime National Wildlife Refuge has the largest sweep, containing a string of islands that would stretch from California to Georgia if superimposed on the lower forty-eight states. Nonetheless, there are some very large refuges outside of Alaska, including Desert (1.6 million acres) in Nevada, Charles M. Russell (910 thousand acres) in Montana, Cabeza Prieta (860 thousand acres) in Arizona, Okefenokee (390 thousand acres) in Georgia and Florida, Hart Mountain (270 thousand acres) in Oregon, Alligator River (160 thousand acres) in North Carolina, and Aransas (114 thousand acres) in Texas. ${ }^{11}$ Several refuges containing key habitats are under 100 acres in size. The smallest, Mille Lacs in Minnesota, logs in at only six-tenths of an acre. ${ }^{12}$

Waterfowl production areas tend to be small, averaging 223 acres in size. ${ }^{13}$ The smallest, North Dakota's Medicine Lake WPA, is less than an acre. The largest, Montana's Kingsbury Lake WPA, is 3,733 acres. ${ }^{14}$

Every state and several territories have at least one unit in the refuge system. The wide distribution of the system is evident in the location of the top three states in numbers of refuge units. North Dakota has sixty-five, California has thirty-eight, and Florida has twenty-nine. ${ }^{15}$ The system's origins in wildlife conservation are evident in its habitats that support more than 700 bird, 220 mammal, 250 reptile and amphibian, and 200 fish

\footnotetext{
${ }^{9}$ FWS LAND REPORT, supra note 1 , at 1.

${ }^{10} \mathrm{Id}$. at 10 tbl.2-25 tbl.3.

${ }^{11} \mathrm{Id}$. at $12-25$ tbl.3.

${ }^{12} I d$.

${ }_{13}$ U.S. Fish \& Wildlife Service, What are Waterfowl Production Areas?, http://www.fws. gov/refuges/faqs/WPAs.html.

14 U.S. Fish \& Wildlife Service, Waterfowl Production Areas: Prairie Jewels of THE REFUGE SYSTEM 1 (July 2002), http://refuges.fws.gov/generalInterest/factSheets/Fact SheetWPA.pdf.

15 FWS LAND REPORT, supra note 1, at 12-25 tbl.3.
} 
species. ${ }^{16}$ The four major bird migration corridors ("flyways") across the U.S., the Atlantic, Mississippi, Central, and Pacific, contain concentrations of hundreds of refuges. These flyway refuges provide breeding, feeding and resting habitat for millions of birds each season. The Waterfowl Production Areas protect thousands of prairie wetlands ("potholes") in an area of the northern plains otherwise dominated by private agricultural land use.

Endangered and threatened species protection has triggered the acquisition of fifty-nine refuges, including Crystal River in Florida for manatees, Ozark Plateau for bats, Hakalau Forest in Hawaii for indigenous birds, and Ash Meadows in Nevada for a variety of imperiled plants and fish. ${ }^{17}$ The system contains a total of 180 animal and 78 plant species listed under the Endangered Species Act. ${ }^{18}$ It also covers a substantial portion of the nation's protected wetlands. In total, more than one-third of the system's acreage is wetlands. ${ }^{19}$

The refuge system shares with the park system a dominant use policy. The Department of the Interior's Fish and Wildlife Service manages the refuge system for the purpose of maintaining, enhancing, and restoring nature. ${ }^{20}$ Congress calls this preeminent goal "conservation." 21 Though other, especially recreational, activities (often called secondary uses) coexist with the paramount conservation use, they must not interfere with attainment of the ultimate objective. ${ }^{22}$ Parts V and VI describe how changes in the way the law has articulated this dominant goal reflect larger trends in conservation policy.

Alas, practice seldom matches theory; and, the refuges suffer from incompatible uses that thwart the systemic aim of nature protection. As recently as 1989, a General Accounting Office study, largely undisputed by the Fish and Wildlife Service, found secondary uses harming conservation goals on nearly 60

${ }^{16} I d$. at 1.

17 U.S Fish \& Wildlife Service, National Wildlife Refuges Established for Endangered Species, http://www.fws.gov/refuges/habitats/EndSpRefuges.html.

18 U.S. Fish \& Wildlife Service, Refuge System Threatened and Endangered Species Database Quicklinks, http://www.fws.gov/refuges/databases/tes.html.

19 U.S. Fish \& Wildlife Service, Wetlands and the National Wildlife Refuge System: Protecting AND Restoring Wetlands 1 (Jan. 2003), http://wetlands.fws.gov/ Pubs_Reports/factsheets/refugesprotectslow.pdf.

${ }_{20}$ National Wildlife Refuge System Improvement Act of 1997, Pub. L. No. 105-57, §

3(a)(4), 111 Stat. 1252 (1997) (codified at 16 U.S.C. § 668ee(4) (2004)).

${ }^{21} I d$.

2216 U.S.C. $\S 460 \mathrm{k}(2000)$. 
percent of refuges. ${ }^{23}$ These uses include off-road vehicle operations, motor boating, mining, and military exercises. ${ }^{24}$

Though it has widened in the past several years, the traditional conservation focus of the refuges has been animals. Unlike most national parks, most refuges are open to hunting, which the Service promotes as part of its legal mission. ${ }^{25}$ Hunters have funded refuge acquisition since the New Deal through the duck stamp program. Currently, the refuges annually host around 2 million hunting and 6 million fishing visits. ${ }^{26}$ Still, the vast majority of visits to the refuges are for wildlife observation. ${ }^{27}$ Nonconsumptive, wildlife-dependent recreation on refuges, such as bird-watching and hiking, generates 30 percent more economic activity than hunting and fishing from over 35.5 million annual visits. $^{28}$

\section{THE SUPERSTAR REFUGE: ARCTIC}

A grasp of the hodgepodge of units that constitute the refuge system is important to understand both the history and the potential of this largest of our nature protection networks. But, it is also revealing in what is missing from the current debate over the superstar Arctic National Wildlife Refuge. This refuge is the superstar of the system in two senses. First, its physical attributes are colossal. At 19.3 million acres, Arctic is the largest refuge in the system. ${ }^{29}$ Moreover, it includes the largest wilderness area in the system, about 8 million acres. ${ }^{30}$ But, the most spectacular attributes of the Arctic refuge are its biological resources. It is the only protected area in the United States that

23 United States General Accounting Office, National Wildlife Refuges: Continuing Problems With InCOMPatible Uses CALl For Bold ACTION 16, 18 (RCED-89196, 1989).

${ }^{24} I d$. at $20-21$.

${ }_{25}$ National Wildlife Refuge System Improvement Act of 1997, Pub. L. No. 105-57, § 5(a)(4)(K), 111 Stat. 1252 (1997) (codified at 16 U.S.C. § 668dd(a)(4)(K) (2004)).

26 U.S. Fish \& Wildlife Service, Providing Quality WildLIFE-DePendant ReCREATION FOR Visitors to the National Wildlife Refuge System (White Paper for the Conservation in Action Summit, May 2004) at 20, http://www.fws.gov/refuges/ ConservationSummit/RecreationTeam/WildlifeDependentRecreationPaper_042604.pdf.

27 Bill Hartwig, Chief, National Wildlife Refuge System, Address at the Conservation in Action Summit (May 25, 2004), http://www.fws.gov/refuges/ConservationSummit/Daily /hartwigSpeech_052504.html.

28 James CaUdhill \& ERIN Henderson, Division of Economics, U.S. Fish \& WildLife Service, BANking on NATURe 2002: The ECONOMic Benefits to Local Communities of NAtional Wildlife Refuge Visitation, at iv (Sept. 2002), http://refuges.fws.gov /policyMakers/pdfs/BankingOnNature2002_101403.pdf.

29 FWS LAND REPORT, supra note 1, at 12-25 tbl.3.

30 U.S Fish \& WildLife Service, ARCTiC NATIONAL Wildlife Refuge (Jan. 2000), http://library.fws.gov/Refuges/arctic00.pdf. 
contains the complete spectrum of arctic ecosystems, from the tallest peaks of the Brooks Range to the marine environment of the Arctic shore. ${ }^{31}$ Its lands host the migration of thousands of caribou, the nesting of hundreds of thousands of diverse migratory waterfowl and shorebirds, and habitat for imperiled species, such as polar bears.

But, in a more revealing sense, the Arctic refuge is a superstar because it is famous. It is the only unit of the system regularly discussed on front-pages of the nation's newspapers. This is, of course, due to the potential of an enormous oil and gas field underlying the coastal plain of the refuge. ${ }^{32}$ The field might be as large as Prudhoe Bay, developed during the 1970s in conjunction with the Trans-Alaska Pipeline. Development of an oil field, however, would impact the Porcupine Caribou Herd, which calves in or near the coastal plain during the summer, and the polar bears, which den in the winter. Development would also threaten the functioning of the vast wetlands complex of the coastal plain, degrade the wilderness character of the refuge, and disrupt the lives of many Alaskan natives. ${ }^{33}$

Since the enactment of the Alaska National Interests Lands Conservation Act in 1980, ${ }^{34}$ the question of whether to drill for oil has been a hardy perennial sprouting in one place or another every year in proposed legislation. Only Congress may allow drilling in the Arctic Refuge, and such legislation is a priority of the current Bush administration. ${ }^{35}$ Drilling opponents have always succeeded in stopping legislation leasing oil in the refuge, though in 1995 it took a presidential veto to win the refuge a last-minute reprieve. ${ }^{36}$ In 2003, the final energy bill drafted by the House-Senate conference committee dropped a House provision authorizing drilling in the Arctic Refuge in the face of a filibuster threat. ${ }^{37}$ That energy bill did not pass and now Congress is poised once again to consider allowing petroleum development in the Arctic

31 Id.

32 See, e.g., Andrew C. Revkin, Clashing Opinions at Meeting on Alaska Drilling, N.Y. Times, Jan. 10, 2001, at A15; Sam Howe Verhovek, Refuge Inside Arctic Circle Is Also in the Middle of U.S. Energy Debate, N.Y. TIMES, Oct. 8, 2000, at A14.

33 National Research Council, Cumulative Environmental EFfects of Oil AND GAS ACTIVITIES ON AlaskA's NORTH SLOPE 1-11 (2003).

34 Codified at 16 U.S.C. $\$ 3101$ (2004).

35 NAtional Energy Policy, Report of the NATional EnERgy Policy Development GrouP (May 2001) at 5-9, 10, 20, http://www.whitehouse.gov/energy/National-EnergyPolicy.pdf; Felicity Barringer, Bush's Record: New Priorities in Environment, N.Y. TIMES, Sept. 14, 2004, at A1.

36 Lynne Corn et al., Arctic National Wildlife Refuge, Issue Brief for Congress (Congressional Research Service IB10094), at CRS-3 (2002).

37 Carl Hulse, Accord Reached by Republicans for Energy Bill, N.Y. TIMES, Nov. 15, 2003, at $\mathrm{A} 1$. 
Refuge. The President included revenues from oil leases in his 2006 budget. By inserting oil drilling language in the upcoming budget resolution, Senate Energy Chairman Pete Domenici hopes to insulate the debate from the filibuster threat. Indeed, the Senate voted by only a fifty-one to forty-nine margin to retain the drilling language in the budget resolution on March 16, 2005. Though other hurdles remain for authorizing petroleum development in the Arctic Refuge, prospects for enacting some kind of drilling permission now appear brighter this year than ever before.

In the controversy over whether petroleum development in the Arctic Refuge is worth the threat to habitat and wilderness, a crucial broader issue has been lost: How will drilling and development affect the 93 million acre Refuge System, of which the Arctic Refuge is only one part? There is a centrifugal, divergent tendency in administering far-flung refuges with disparate establishment purposes. Proponents of drilling like to call the Arctic Refuge "ANWR" ("An-wahr"), ${ }^{38}$ which obscures its identity as a node in a larger network of habitat reserves. Current debates over drilling in the refuge are almost completely devoid of systemic concerns, and instead discuss the refuge as though it were unconnected to a larger web of reserves managed for large-scale conservation goals. The great contemporary challenge for the refuge system is how to orchestrate individual units for large-scale ecological protection. This is no easy task.

But, Congress sought to simplify the management challenge in 1997 by establishing a hierarchy of acceptable uses for the refuges. ${ }^{39}$ Unlike recreational uses, which may merely be compatible with the mission, commercial development must make affirmative contributions to the system's conservation mission. ${ }^{40}$ Otherwise, the risks that economic uses of individual refuges pose to the refuge system could not be justified.

To frame the debate solely in fiscal terms, or even in terms of allowable harm to the refuge, misses the mark. It turns the clock back to the days when we thought we could protect nature by saving isolated fragments. Instead, drilling proponents ought to

38 See, e.g., Lynn Scarlett, An Address to the Natural Resources under the Bush Administration Symposium, 14 DUKE ENVTL. L \& POL'Y F. 281, 285 (2004).

${ }^{39}$ National Wildlife Refuge System Improvement Act of $1997 \S 5(\mathrm{a})(3)(\mathrm{C})$ (codified at 16 U.S.C. $§ 668 d d(a)(3)(C)$ (2004)); GeORge CAMERon Coggins \& RoberT L. Glicksman, PubliC NATURAL RESOURCE LAW 14A:5 (Clark Boardman Callaghan, 1992) (2002); Robert L. Fischman, The National Wildlife Refuge System and the Hallmarks of Modern Organic Legislation, 29 EcOLOGY L. Q. 457, 526-38 (2002).

4050 C.F.R. $\S 29.1$ (2005). See also Final Compatibility Regulations Pursuant to the National Wildlife Refuge System Improvement Act of 1997, 65 Fed. Reg. 62,472, 62,484 (Oct. 18, 2000). 
explain how petroleum development advances the conservation mission of the Refuge System as a whole, or why the Arctic Refuge does not belong in this vital system of environmental protection. To do less threatens not only this one refuge, but the entire Refuge System and its historic contributions to the conservation gains of the past century.

\section{THE FIRST REFUGE: THE PELICAN ISLAND SANCTUARY}

Pelican Island, some forty-five miles south of Cape Canaveral, is located within the Indian River Lagoon, and lies in the biologically diverse zone where subtropical and temperate habitats overlap. ${ }^{41}$ At first blush, one can hardly think of a place farther removed from the debates over drilling in the Arctic coastal plain. But, Pelican Island is connected to the Arctic debate because it is another node in the refuge system. While the Arctic Refuge anchors the system in size and biological integrity, the Pelican Island Refuge anchors the system historically. It is widely regarded as the very first national wildlife refuge. ${ }^{42}$

The Pelican Island refuge contains seagrass beds, oyster bars, mangrove islands, salt marsh, and maritime hammocks. But, it is best known for the birds that use this habitat. It was the birds that attracted the German immigrant homesteader, Paul Kroegel, in the late nineteenth century to act as warden to protect Pelican Island. ${ }^{43}$ First as a self-appointed volunteer, then as an Audubon Society-American Ornithological Union employee, and finally as the first refuge manager, Kroegel exemplifies the citizenactivists who shaped the refuge system. ${ }^{44}$ To this day, the FWS achieves many of its conservation successes in partnership with its neighbors and citizen supporters. ${ }^{45}$

Early visitors to Pelican Island described it as "draped in white, its trees seemingly covered with snow." 46 This "snow," derived both from feathers and guano, resulted from the masses of birds that flocked to the island. Unfortunately, the plumage birds, egrets, ibises, roseate spoonbills, also attracted market hunters,

\footnotetext{
41 U.S Fish \& Wildlife Service, Pelican Island National Wildlife Refuge (Sept. 2002), http://library.fws.gov/Refuges/pelicanisland02.pdf.

${ }^{42} I d$.

${ }^{43} I d$.

${ }^{4} I d$.

${ }^{45}$ See, e.g., id; FWS LAND REPORT, supra note 1 , at 1.

${ }^{46}$ William Reffalt, Prologue to Pelican Island 1 (unpublished 2003), http://refuges.fws. gov/centennial/pdf2/pelicanIsland_reffalt.pdf.
} 
who decimated populations to supply the costume and fashion industry. ${ }^{47}$

The steep, steady decline of birds in this rich habitat attracted the attention of Frank Chapman, a bird curator at New York's American Museum of Natural History, author of many bird books, and founder of Bird-Lore (the Audubon Societies' magazine). ${ }^{48}$ Chapman was involved in the American Ornithological Union and the fledgling Audubon Society. He traveled among the well-connected circles of elite New York. ${ }^{49}$ Chapman, a dedicated worker, even enlisted his new bride to skin and prepare pelicans during their honeymoon visit to Pelican Island. ${ }^{50}$ Chapman exemplifies the contributions made to refuge protection by professional scientists.

Working with the American Ornithological Union, Chapman helped enact a wildlife protection statute in Florida and was pushing to acquire Pelican Island, when the Bureau of Biological Survey suggested instead a federal sanctuary. ${ }^{51}$ The sanctuary idea found a sympathetic audience in President Theodore Roosevelt, who declared Pelican Island "a preserve and breeding ground for native birds" in 1903. ${ }^{52}$ The Bureau of Biological Survey, under the leadership of another scientist, C. Hart Merriam, became the first federal manager of most of the early refuges. The Biological Survey merged with the Bureau of Fisheries in 1940 to create U.S. Fish and Wildlife Service. ${ }^{53}$

President Theodore Roosevelt, of course, personifies the ascendancy of Progressive Era conservation as necessary for sustaining national prosperity. However, he also talked about conservation as a moral issue. Using his bully pulpit, Roosevelt exemplifies the expansive presidential assertion of power that pioneered most of the new conservation innovations on the refuges. ${ }^{54}$ By the end of his term, Roosevelt had designated more

47 Id.

48 Id.; Frank M. Chapman, Autobiography of A BiRD-Lover 187 (1933).

49 Reffalt, supra note 46 , at 1.

50 See CHAPMAN, supra note 48 , at 161.

51 At the time, the principal leaders in conservation for the Bureau of Biological Survey, the American Ornithological Union, the fledgling Audubon Society, and the American Museum of Natural History, overlapped substantially. Stephen Fox goes so far as to claim that the boundaries between these institutions blurred. See STEPHEN FOX, JOHN MUIR AND His LEGACY: THE AMERICAN CONSERVATION MOVEMENT 173 (1981).

52 Executive Order of March 14, 1903, microformed on CIS Presidential Executive Orders \& Proclamations (1986) (1903-41-5).

53 Reorg. Plan No. 3 of 1940, 5 Fed. Reg. 2107, 2108 (June 4, 1940), reprinted in 54 Stat. 1231, 1232 (1940).

${ }_{54}$ Charles Wilkinson, Clinton Learns the Art of Audacity, High CounTRY NEWs, Sept. 30, 1996, http://www.hcn.org/servlets.hen.Article?article_id=2799. 
than fifty refuges and spurred Congress to endorse the enterprise. ${ }^{55}$

Though a couple of earlier executive orders by Benjamin Harrison ${ }^{56}$ and William McKinley ${ }^{57}$ have some claim as precedents for presidential establishment of wildlife sanctuaries, they both relied on legislation authorizing the forest reserves that became the national forests. ${ }^{58}$ The 1903 Roosevelt proclamation created a brand new designation under inherent executive authority. It truly did open the door to a new system governed not by multiple use principles, but by the dominant use philosophy that all activities on refuges should be compatible with wildlife protection. National wildlife refuge management, first under the control of the Bureau of Biological Survey and later the U.S. Fish and Wildlife Service, has always used and developed science as a basis for making decisions.

\section{GROWTH AND CONSOLIDATION: ENCLAVES TO FLYWAYS}

In the decades following the establishment of the Pelican Island refuge, the number of refuges grew. However, it was not until the next Roosevelt, F.D.R., took office that the rate of growth accelerated and early efforts were made to sew together refuges into a conservation system. Two developments converged in the mid-1930s to fuel growth and consolidation.

First, Congress enacted the Duck Stamp Act in 1934, which dedicated revenue from the sale of migratory bird hunting stamps that all hunters of waterfowl have to affix to their state hunting licenses, to be used for habitat acquisition. ${ }^{59}$ Though earlier statutes had authorized acquisition of habitat for improving existing, and establishing new, refuges, the lack of appropriations had hampered the program. ${ }^{60}$ Since 1934, the duck stamp funds have been a steady source for refuge system expansion. The duck stamp program also strengthened the ties between the hunting community and the refuges.

Second, largely through Bureau of Biological Survey research, scientists were learning more about the life cycles and

\footnotetext{
55 Rachel F. Levin, Leading the Way...Early Pioneers of the Refuge System, FiSH \& WILDLIFE NEWS, Mar./Apr. 2000, at 14.

${ }^{56}$ See Proclamation No. 39, 27 Stat. 1052 (Dec. 24, 1892).

57 See Proclamation No. 5, 32 Stat. 1973 (July 4, 1901).

58 See General Revision Act of Mar. 3, 1891, ch. 561, 26 Stat. 1095, 1103 (repealed by 90 Stat. 2792)

59 See Migratory Bird Conservation Act, ch. 257, § 5, 45 Stat. 1222, 1223 (1929) (codified at 16 U.S.C. $\S 715(d)(2004))$.

60 See Nathanial P. Reed \& Dennis Drabelle, The United States Fish \& Wildlife SERVICE 8 (Westview Press 1984).
} 
geographic patterns of migratory birds. ${ }^{61}$ By the mid-1930s, the four principal flyways running north-south across the lower fortyeight states were well delineated. ${ }^{62}$ Conservation policy shifted from the Pelican Island-era concern of protecting a few rich sites of wildlife habitat to maintaining a series of connected, steppingstone habitats that birds could use in their migrations. ${ }^{63}$ A quick glance at a map of today's refuge system confirms the legacy of this insight. Refuges are concentrated in four north-south corridors. The geometry of refuge management shifted from the enclave points on the map to the flyway lines across the country.

And so, the system grew from 63 units in 1934 to 204 units in 1944. ${ }^{64}$ The effort to link refuges together to achieve the largerscale goal of migratory bird conservation was reflected in F.D.R.'s 1940 order to rename nearly 200 units to reflect their common mission. ${ }^{65}$ The Franklin Roosevelt proclamation converted "reservations," "bird refuges," "migratory waterfowl refuges" and "wildlife refuges" to "national wildlife refuges," and the name stuck. ${ }^{66}$ Though part of the impetus behind the common mission came from international treaty commitments and hunters' interests, science strongly influenced the consolidation of units around the national wildlife refuge mission of conservation.

After the Franklin Roosevelt Administration, the next great steps toward greater coordination of units in the name of science did not occur until the 1960s. Increased concern about species extinction and developments in the field of ecology began to transform the mission of the refuge system.

In 1966, Congress enacted its first statute dealing with species extinction as a general category of concern. Though Congress had previously addressed depletion of particular stocks of certain species, ${ }^{67}$ the 1966 law plowed new ground in creating an open-ended category of "endangered species." 68 The plan was for species, regardless of their popularity or evident value, to receive special consideration as they slipped toward the brink of extinction. The 1966 law relied principally on habitat acquisition

\footnotetext{
61 See Ira N. Gabrielson, Obituary_Frederick Lincoln, 79 THE AuK 495 (1961).

62 See Frederick C. Lincoln, The Migration of North American Birds, U.S. DEPT. OF AGRIC. CIRCUlAR No. 353, 33 (Oct. 1935).

${ }^{63}$ See IRA N. Gabrielson, WiLdlife Refuges 135 (1943).

64 Robert L. Fischman, The National Wildlife Refuges: Coordinating a CONSERVATION SYSTEM THROUGH LAW 38 (2003).

${ }^{65}$ See Proclamation No. 2416, 54 Stat. 2717 (July 25, 1940).

${ }^{66} I d$.

67 See, e.g., The Migratory Bird Treaty Act of 1918, ch. 128, 40 Stat. 755; The Black Bass Act of 1929, ch. 346, 44 Stat. 576; The Bald and Golden Eagle Protection Act of 1940, ch. 278, 54 Stat. 250.

68 Endangered Species Preservation Act of 1966, Pub. L. No. 89-669, § 1-3, 80 Stat. 926.
} 
to recover species populations. 69 In doing so, the law provided the first statutory charter for the refuge system as a whole, and gave the Interior Department a new source of money, the Land and Water Conservation Fund, to acquire refuge acreage. ${ }^{70}$

The part of the 1966 law dealing with the refuges is often called the Refuge Administration Act. ${ }^{71}$ Its basic framework for refuge administration remains in place today, though it has been substantially revised by the 1997 Refuge Improvement Act. ${ }^{72}$ Any understanding of the legislative origins of refuge consolidation and comprehensive management must start with the 1966 law whose focus was endangered species protection. The preservation imperative for the refuge system is part of a larger trend that swept natural resources law in the 1960s. In addition to the endangered species law, it included the 1964 Wilderness Act ${ }^{73}$ and the 1968 Wild and Scenic Rivers Act. ${ }^{74}$

The 1966 statute consolidated the conservation land holdings of the FWS into a system: it was the first statute to refer to this hodgepodge as the "National Wildlife Refuge System." 75 The law also mandated a uniform use management rule, ${ }^{76}$ borrowing the compatibility principle from the 1962 Refuge Recreation Act. ${ }^{77}$ The 1966 law closed the system to all uses except those that the Service determined would be compatible with the purpose of the refuge on which they occur. ${ }^{78}$ The compatibility criterion, established by statute in 1966 but practiced by the Service for decades before that, would become a byword of international sustainable development in the 1980s.

${ }^{69} \mathrm{Id}$.

${ }^{70}$ Land and Water Conservation Fund Act of 1965 ("LWCFA"), Pub. L. No. 88-578, 78 Stat. 897 (1964) (codified at 16 U.S.C. $\$ \$ 4601-4$ to 460l-11 (2004)). The LWCF earmarks a percentage of offshore oil and gas lease receipts and other sources of federal revenue to finance public land acquisition. Agencies may not spend the money, however, unless Congress appropriates it. Appropriations generally fall far short of the earmarked funds authorized. COGGINS \&GLICKMAN, supra note 39, at sec. 10C:44.

${ }_{71}$ National Wildlife Refuge System Administration Act, Pub. L. No. 89-669, § 1(a), 80 Stat. 926 (1966) (codified at 16 U.S.C. § 668dd(d)(1)(a) (2000)).

72 National Wildlife Refuge System Improvement Act of 1997, Pub. L. No. 105-57, 111 Stat. 1252, 1257 ("[a]n Act to amend the National Wildlife Refuge System Administration Act of 1966 ..." ).

${ }^{73}$ Wilderness Act, Pub. L. No. 88-577, 78 Stat. 890 (1964) (codified at 16 U.S.C. § 1131-36 (2004)).

${ }^{74}$ National Wild and Scenic Rivers Act, Pub. L. No. 90-542, 82 Stat. 906 (1968) (codified at 16 U.S.C. $§ 1271-87$ (2004)).

${ }^{75}$ National Wildlife Refuge System Administration Act, Pub. L. No. 89-669, § 1(a), 80 Stat. 926 (1966) (codified at 16 U.S.C. § 668dd(a)(1) (2004)).

${ }^{76}$ Id. $\S 4(\mathrm{~d}), 80$ Stat. 928.

77 Refuge Recreation Act, Pub. L. No. 87-714, § 1, 76 Stat. 653 (1962) (codified as amended at 16 U.S.C. $§ 460 \mathrm{k}(2000))$.

${ }^{78} I d$. 
The 1960s also saw a new wave of science influence refuge management. In 1967, Edward O. Wilson and Robert MacArthur published their path-breaking monograph, The Theory of Island Biogeography. Application of this new theory viewed refuges as small, isolated islands, vulnerable to species extinctions regardless of how well they are managed. ${ }^{79}$ The theory taught that refuges, even if maintained in pristine condition, were not sufficient to prevent species extinction unless they were large enough and linked to other protected areas. ${ }^{80}$ Small pockets of species do not persist long anywhere.

The rise of ecology as a scientific basis for management in the 1960s is exemplified in the Leopold reports. In 1963, Professor A. Starker Leopold, a son of the famous Aldo, led a committee that recommended national park management strive to maintain and restore native species in their natural, biotic associations. ${ }^{81}$ This recommendation was updated and applied to the refuge system in a similar 1968 report prepared at the request of the Secretary of the Interior. ${ }^{82}$ The 1968 Leopold committee report described the long-range systemic goal for the refuges to serve as show places for the full spectrum of native wildlife. ${ }^{83}$ The committee proposed "to add a 'natural ecosystem' component to the program of refuge management." ${ }^{4}$ In this recommendation, the Leopold committee sought an overarching, guiding principle that would provide a uniform direction for system management and respond to growing ecological concerns about the viability of isolated reserves. Though it anticipated by three decades the formal FWS adoption of an ecosystem management policy, ${ }^{85}$ it nudged the refuges toward the forefront of conservation.

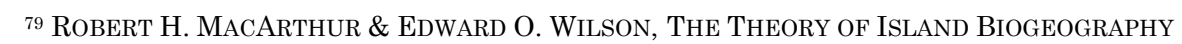
3-7, 121-122, 182 (Princeton University Press 1967).

80 See id. at 180-81.

81 A. Starker Leopold et al., Wildlife Management in the National Parks: The LEOPOLD REPORT 4 (1963) (reprinted by the U.S. Department of the Interior, National Park Service), http://www.cr.nps.gov/history/online_books/leopold/leopold.htm.

82 Advisory Comm. ON Wildlife Management, appointed by Interior Sec. Stewart L. Udall, REPORT ON THE NATiONAL WiLDLIFE REFUGE SYSTEM (1968), reprinted in U.S. Fish and Wildlife, Final ENVIronmental Statement, Operation of the NATiONAL WiLdLife REFUGE SYSTEM app. W (1979).

${ }^{83} \mathrm{Id}$. at $\mathrm{W}-3, \mathrm{~W}-22$.

${ }^{84} \mathrm{Id}$. at W-4.

${ }^{85}$ See U.S. Dept. of the Interior, Fish and Wildlife Service, National Policy Issuance \#9503, Ecosystem Approach to Fish and Wildlife Conservation (effective Feb. 9, 1995), http://policy.fws.gov/npi95_03.html. 


\section{THE RECENT ERA: ECOSYSTEM MANAGEMENT}

The refuge system spent the 1970s and 1980s lagging behind the enormous changes that affected other federal lands. With the exception of the 1980 Alaska National Interest Lands Conservation Act, ${ }^{86}$ Congress enacted few significant legislative reforms specific to the refuges. In the 1970s, the Forest Service ${ }^{87}$ and Bureau of Land Management (BLM) ${ }^{88}$ received completely new statutory charters governing their public land management, and the National Park Service obtained a substantial revision of its legislative mandate. ${ }^{89}$ But the FWS limped along with its 1966 framework.

As with other federal lands, the refuges began to shift toward a more ecological approach to management as a result of scientific developments, environmental statutes (such as NEPA and the ESA), and the opening of the courts to hear citizen environmental complaints. Nonetheless, conditions on the refuges were poor. A combination of austere funding, lax oversight, limited jurisdiction, and local political pressure gave rise to widespread incompatible uses on refuges. An important 1989 GAO report found incompatible uses harming conservation goals on 59 percent of refuges. ${ }^{90}$ Among the most commonly occurring secondary activities were mining, off-road vehicle use, power boating, military exercises, grazing, logging, hunting, and rights of way use. ${ }^{91}$

In response to the GAO report, a lawsuit, ${ }^{92}$ and several follow-up studies that confirmed the major problems with

\footnotetext{
${ }^{86}$ Alaska National Interest Lands Conservation Act, Pub. L. No. 96-487, 94 Stat. 2371 (1980) (codified as amended in scattered sections of 16 U.S.C.).

${ }^{87}$ Forest and Rangeland Renewable Resources Planning Act of 1974, Pub. L. No. 93-378, 88 Stat. 476, amended by National Forest Management Act of 1976, Pub. L. No. 94-588, 90 Stat. 2949 (codified as amended at 16 U.S.C. 1600-1614 (2000)).

88 Federal Land Policy and Management Act of 1976 ("FLPMA"), Pub. L. No. 94-579, 90 Stat. 2744 (codified at 43 U.S.C. 1701 et. seq. (2004)).

89 National Park System General Authorities Act of 1970, Pub. L. No. 91-383, 84 Stat. 825; Redwood Amendment Act of 1978, Pub. L. No. 95-250, 92 Stat. 163; National Parks and Recreation Act of 1978, Pub. L. No. 95-625, 92 Stat. 3467, 3518 (codified as amended at 16 U.S.C. $1 \mathrm{a}-1$ to 8 (2000)).

90 United States General Accounting Office, National Wildlife Refuges: Continuing Problems With InCOMPatible UsEs CALl For Bold ACTION 16, 18 (RCED-89196, 1989).

${ }_{91} I d$. at $20-21$.

92 The plaintiffs, who included the Wilderness Society, National Audubon Society, and Defenders of Wildlife, claimed that the Service was continuing to allow incompatible recreational and commercial uses on specified refuges. They also challenged the process by which the Service approved uses throughout the System. S. Rep. No. 103-324, at 6-7 (1994). See also Cam Tredennick, The National Wildlife System Improvement Act of 1997: Defining the National Wildlife Refuge System for the Twenty-First Century, 12 FoRDHAM ENVTL. L.J. 41, 70-71 (2000) (describing the litigation and its political aftermath).
} 
incompatible uses, ${ }^{93}$ Congress enacted the 1997 Refuge Improvement Act. ${ }^{94}$ That new charter for the refuge system, as interpreted through FWS policies in 2000 and 2001, reestablishes refuge management as a leading exemplar of conservation policy that it was in its beginning at Pelican Island.

The most important aspect of the new refuge management regime is that it has a clear statutory goal of conservation, defined in ecological terms. The refuge conservation mission is defined by statute as being for animals, plants, and their habitats. ${ }^{95}$ This is a very different conception of conservation from the progressive-era, multiple-use, sustained yield missions that sought to conserve a steady stream of commodities to be extracted from the public lands. It also embraces a broader land (and water) ethic that extends to plants and habitat than the earlier refuge goals, which focused on animals ("wildlife") almost exclusively. The FWS is directed by the statutory mission "to sustain and, where appropriate, restore and enhance, healthy populations of fish, wildlife, and plants utilizing . . . methods and procedures associated with modern scientific resource programs."96 The 1997 conservation mandate finally provided a unifying mission for a system that retains a disparate set of establishment purposes for individual refuges.

Moreover, refuge administration now recognizes a key lesson of conservation biology: nature reserves need to be interconnected. The 1997 statute defined the mission of the refuge system to serve as a "national network" of lands and waters to sustain plants and animals. ${ }^{97}$ This realigns the geometry of refuge conservation from linear flyways to a more complex web of relationships.

The importance of the new systemic mission is not merely its ecological argot. The mission establishes a bottom line for management. The FWS may not permit uses to occur where they are incompatible with the conservation purpose of the system.98 Moreover, economic uses must contribute to attaining the

93 U.S. Department OF THE INTERIOR InspeCtor GENERAL, SURVEy Report: Maintenance of Wildlife Refuges (1993); Senate Comm. on EnVironment AND Public Works, National Wildlife Refuge System Management and Policy ACt of 1994, S. Rep. No. 103-324, at 6 (1994); Michael J. BEAN \& MELANiE J. Rowland, The Evolution OF NATIONAL WildLife LAW 292-93 (3d ed. 1997) (citing U.S. Fish \& WildLIFE SERVice, Audubon ET AL. V. BABBitT - FinAl RePORT (Dec. 1994)).

${ }_{94}$ National Wildlife Refuge System Improvement Act of 1997, Pub. L. No. 105-57, 111 Stat. 1252 (1997) (codified at 16 U.S.C. § 668dd-ee (2004)).

${ }_{95} I d . \S 4$.

${ }^{96} I d . \S 5(4)$.

${ }^{97} I d . \S 4$.

${ }^{98} \operatorname{Id} . \S 3(\mathrm{a})(1)$. 
conservation mission. ${ }^{99}$ This clear command to maintain ecological functions (rather than resource outputs) on the refuges represents the current trend for all public land management. In his thoughtful and cautious book, Keeping Faith with Nature, Professor Robert Keiter suggests that Congress establish biodiversity conservation and ecosystem protection as clear priorities for the public lands. ${ }^{100}$ The refuge system is leading the way.

But there is more. In an effort to hold the FWS accountable to the broad purpose for the refuge system, Congress imposed a number of path-breaking substantive management criteria. In addition to a revised compatibility determination that the Service must now put in writing, the 1997 law requires that the Service maintain "biological integrity, diversity, and environmental health" 101 on the refuges. This is the most ecological standard in all of U.S. public land law. It represents a return of the refuge system to the cutting edge of conservation. Almost all definitions of ecosystem management include at least one if not more of the three key phrases (integrity, diversity, and health). And ecosystem management, viewing ecological sustainability as the baseline condition of public land uses, is where a century of conservation has led us. ${ }^{102}$

The FWS policies implementing the 1997 law push refuge management even further toward the head of the pack in the practice of twenty-first-century conservation. For instance, a 2000 Service policy finds incompatible those uses that reasonably may be anticipated to cause habitat fragmentation, ${ }^{103}$ one of the chief villains identified by island biogeography and conservation biology in the decline of species. ${ }^{104}$ The only other management criterion that comes close to this as a manifestation of the best science applied to public land administration is the superseded minimum viable population standard for national forest management that

9950 C.F.R. $§ 29.1$ (2005); Final Compatibility Policy Pursuant to the National Wildlife Refuge System Improvement Act of 1997, 65 Fed. Reg. 62,472, 62,484 (Oct. 18, 2000).

100 RoBert B. KeITER, KeEPING FAITH With NATURE 66 (2003).

101 National Wildlife Refuge System Improvement Act of 1997, Pub. L. No. 105-57, 5(a)(4)(B), 111 Stat. 1252 (codified at 16 U.S.C. § 668dd(a)(4)(B) (2004)).

102 See KeITER, supra note 100, at 71-75; R. Edward Grumbine, Reflections on "What Is Ecosystem Management?”, 11 CONSERVATION BIOLOGY 41 (1997).

103 Final Compatibility Policy Pursuant to the National Wildlife Refuge System Improvement Act of 1997, 65 Fed. Reg. 62,484, 62,486 (Oct. 18, 2000).

${ }_{104}$ Conservation biologists agree that fragmentation of wildlife habitats is a direct threat to biological integrity. See NATIONAL RESEARCh Council, Science AND the Endangered Species ACt (1995); Reed F. Noss et AL., The Science of Conservation Planning: Habitat Conservation Under the EndANGERED SpeCIEs ACT (1997); LARRY D. HaRRIS, The Fragmented Forest: Island Biogeography Theory and the Preservation of BIOTIC DIVERSITY (1984). 
both the Bush and Clinton administrations abandoned in successive rulemakings. ${ }^{105}$

Another significant implementing policy addresses external threats to refuge resources under the mandate to maintain biological integrity, diversity, and environmental health. External threats are those sources of degradation that originate from actions that occur outside of the refuge boundary. ${ }^{106}$ The Service policy advises refuge managers to seek redress before local planning and zoning boards, and state administrative and regulatory agencies, if voluntary or collaborative attempts to forge solutions do not work. ${ }^{107}$ Though tempered by cautionary language, these are nonetheless bold instructions for a traditionally timid agency. The manual provision on external threats joins with mandates for planning and other management criteria to strengthen trans-boundary coordination, which is universally acclaimed as necessary to achieve ecosystem conservation. ${ }^{108}$

The external threat to public lands is one of the most serious hurdles to achieving the conservation mission on a scattershot system. Because refuges, compared to national forests and national parks, tend to concentrate in wet areas at the lower reaches of watersheds, the refuge system faces particularly difficult trans-boundary problems. Chemical run-off and soil erosion from upstream farming, oil and gas extraction, and residential development degrade refuges throughout the system. ${ }^{109}$ How the Service responds to these external threats will be an early indication of the effectiveness of the strong language in the refuge policy to secure biological integrity, diversity and environmental health. It will also prompt collaborative coalition-building to address watershed-level concerns.

\footnotetext{
105 The original criterion is found in the regulations establishing criteria for land and resource management plans. National Forest System Land and Resource Management Planning, 47 Fed. Reg. 43,026, 43,050 (Sept. 30, 1982). The Clinton Administration repeal is found at the final planning regulations. National Forest System Land and Resource Management Planning, 65 Fed. Reg. 67,514 (Nov. 9, 2000). The Bush Administration repeal is found at the final planning regulation. 70 Fed. Reg. 1023 (Jan. 5, 2005).

106 Policy on Maintaining the Biological Integrity, Diversity, and Environmental Health of the National Wildlife Refuge System, 66 Fed. Reg. 3,810, 3,822 (Jan. 16, 2001).

107 See id.

108 See, e.g., KEITER, supra note 100, at 72.

109 See, e.g., U.S. FISH \&WILDLIFE SERVICE, Division OF ENVIRONMENTAL COntaminants, CONTAMinant Assessment Process - Summary RePORTS, http://ecos.fws. gov/cap/viewPublicSummaries.do; Anne Criss, Refuges at Risk, NAT'L WETLANDS NEWS (Envtl. Law Inst.), July-Aug. 1999, at 1, 13; PAul J. Conzelmann \& Thomas W. Schultz, U.S. Fish \&Wildlife Service, UpPer Ouachita NAtional Wildlife Refuge Contaminants StUdy 1989-1990 iv (1992); C.M. Pringle, Threats to U.S. Public Lands from Cumulative Hydrologic Alterations Outside of Their Boundaries, 10 ECOLOGICAL APPLICATIONS 971 (2000).
} 
Facing construction of a 19,250-seat, concert amphitheater on a tract of land adjacent to the Minnesota Valley National Wildlife Refuge, the Service demonstrated the promise and power of the external threats portion of the integrity, diversity, and health policy. The refuge staff carefully documented how the amphitheater would project noise, nighttime light, and stormwater into the refuge, and negatively affect refuge resources and priority public uses. They took measures to ensure that these concerns were incorporated into the formal environmental impact analysis of the proposed project, ${ }^{110}$ and the Service followed the policy's prescription to raise concerns in the context of local land use procedures. The FWS Regional Director testified in opposition to the project's conditional use permit before the county commission. In the face of the Service's well-documented opposition, which was amplified by the refuge friends organization, the county commissioners unanimously rejected the permit application. ${ }^{111}$

The final respect in which the refuges are tracking the development of conservation policy is in the field of restoration. Restoration goes beyond maintaining minimum ecological vital signs. It seeks affirmative, long-term commitments to reversing past harms to natural systems. The 1997 statutory mission of the system includes restoration, where appropriate, of plants and animals. ${ }^{112}$ This mission is reflected in three unusual affirmative obligations in the statutory management criteria. First, the FWS has a duty to acquire water rights, ${ }^{113}$ the only affirmative trust mandate of its kind in U.S. public land law. Because instream flow problems in refuges are generally caused by upstream users outside of the refuge boundaries, this provision supports the commitment to abate external threats stated in the biological integrity, diversity, and environmental health policy.

Second, the 1997 statute requires the Service to "monitor the status and trends" 114 of animals and plants in each refuge. This biological monitoring duty will prompt development of an essential, yet chronically missing, element of adaptive management. Adaptive management, another component of most definitions of ecosystem management, requires feedback about the

\footnotetext{
110 Scott County EnVironmental REview, Final Environmental ImpaCt STATEMENT, Q PRIMe AMPHiThEATER (Jan. 23, 2004), http://www.co.scott.mn.us/xpedio/groups/public/ documents/web_files/cs_csqprimefinal.hcsp.

111 Scott County, Minnesota, BoARd of Commissioners Minutes (June 29, 2004), http://www.co.scott.mn.us/xpedio/groups/public/documents/web_files/do_2004coboardminute sframe.hcsp.

112 National Wildlife Refuge System Improvement Act of 1997, Pub. L. No. 105-57, § 4, 111 Stat. 1252, 1254 (1997) (codified at 16 U.S.C. § 668dd(a)(2) (2004)).

113 Id. § $5(\mathrm{a})(4)(\mathrm{G})$.

${ }^{114} I d . \S 5(\mathrm{a})(4)(\mathrm{N})$.
} 
consequences of decisions in order to adjust them continually. ${ }^{115}$ Public land management, generally, lacks a research component that adequately evaluates the success of predictions, such as a prospective finding of compatibility. Therefore, implementation of this biological monitoring criterion will facilitate the Service's policy of employing adaptive management in planning, and consequently, ecosystem management as well.

Third, the Service now has an affirmative conservation stewardship duty. ${ }^{116}$ This looks to the future when the system will face problems not specifically addressed in the current law. While it will initially be used as a shield by the Service to defend protective actions, it may ultimately be wielded as a sword to advance the restoration goal, the mission, and the substantive management criterion to maintain biological integrity, diversity, and environmental health. ${ }^{117}$

\section{CONCLUSION}

The specific examples of the Pelican Island and the Arctic National Wildlife Refuges serve as bookends to a historical review of the conservation challenges of the past hundred years. Pelican Island reflects the early refuge function as an isolated sanctuary where habitat could be maintained for hunted animals. Over time, however, conservation approaches recognized the inadequacies of a zoo-like collection of rich habitats. Slowly, coordination among refuges, and between refuges and their surrounding neighbors, has emerged as a critical theme in building a true system out of the disparate hodgepodge of refuge units. The failure to consider the interconnected impacts from drilling for oil in the Arctic Refuge on the larger FWS conservation network reveals the shortcomings of the current management regime: the refuges do not yet fully cohere into a system that is more than the sum of its parts. The web remains frayed and patchy.

115 Reed F. Noss, Some Principles of Conservation Biology, As They Apply to Environmental Law, 69 CHI-KenT L. REv. 893, 907; KeITER, supra note 100, at 73. See generally KAI N. LEE, COMPASS \& GYROSCOPE: INTEGRATING SCIENCE AND POLITICS FOR THE

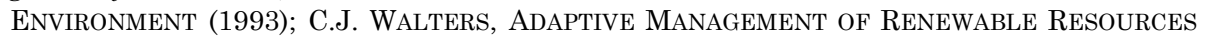
(1986).

116 The National Wildlife Refuge System Improvement Act of 1997, Pub. L. No. 105-57, § 5(a)(3)(A), 111 Stat. 1252, 1254 (1997) (codified at 16 U.S.C. § 668dd(a)(3)(A) (2004)) ("each refuge shall be managed to fulfill the mission of the System ..." ").

${ }^{117}$ I borrow the shield and sword images from J.B. Ruhl's study of the ESA's affirmative conservation mandate, a provision the Improvement Act's conservation stewardship duty closely resembles. J.B. Ruhl, Section 7(a)(1) of the "New" Endangered Species Act: Rediscovering and Redefining the Untapped Power of Federal Agencies' Duty to Conserve Species, 25 ENVTL. L. 1107, 1129-34 (1995). 
The typicalness of the refuge system makes it the ideal vehicle for exploring the history of conservation. But it also makes the system a kind of type-O, universal donor for conservation policy. In its unobtrusive way, the system offers important lessons that are far more adaptable to non-federal land conservation than the experiences of our more prominent nature reserves. In the United States we tend to regard the national parks (think Yellowstone) and the wilderness areas (think Bob Marshall or River of No Return) as the pinnacles of federal conservation. However, both of these land systems grew out of peculiarly American notions of a monumental, pristine, uninhabited nature that are not widely shared in other cultures.

In contrast, the refuge system's management policy is articulated in the lingua franca of international conservation policy: ecology and sustainable development. The refuge system's interpretation of ecology through the mandate to maintain biological integrity, diversity, and environmental health, and its model of sustainability through limiting uses to those compatible with the dominant conservation mission, deserve special attention as contributions to the international conservation agenda. Existing international programs already recognize this aspect of refuge management. The U.N. has designated biosphere reserves that contain five refuges. ${ }^{118}$ The Ramsar Convention's wetlands of international importance include twenty national wildlife refuges. ${ }^{119}$ The Western Hemisphere Shorebird Reserve Network has also designated twenty refuges as essential habitat for migratory shorebirds. ${ }^{120}$ More generally, the persistent challenges of limiting incompatible uses and coordinating a crazy-quilt system to achieve large-scale goals are as typical of the refuges as they are of nature reserves around the world.

The 1992 Rio Earth Summit, and its Agenda 21, established an international commitment to promote economic prosperity in a manner that safeguards our natural heritage. ${ }^{121}$ Yet, the United States has no national program for attaining sustainable development and no official criteria with which to measure progress. The National Wildlife Refuge System's operating

\footnotetext{
118 U.S. Fish \& Wildlife Service, Special Management AReas: Biosphere Reserves, http://www.fws.gov/refuges/habitats/specialAreas.html.

119 U.S. Fish \& WildLIFE SERVICE, WETLANDS OF InTERnATIONAL IMPORTANCE, http:// www.fws.gov/refuges/habitats/ramsar.html. See also Daniel Navid, The International Law of Migratory Species: The Ramsar Convention, 29 NAT. RESOURCES J. 1001 (1989), for a general overview of the Ramsar Convention.

120 U.S. Fish \& Wildlife Service, SPecial Management Areas: Western Hemisphere SHOREBIRD RESERVE NETWORK, http://www.fws.gov/refuges/habitats/specialAreas.html.

121 John C. Dernbach, Sustainable Development: Now More Than Ever, in STUMBLInG TOWARD SustainabiLiTY 45, 45-46 (John C. Dernbach ed., 2002).
} 
principles, though not explicitly designed to fulfill our obligation to sustainable development, nonetheless offer a powerful case study in coordinated conservation management. Refuge management has the potential to serve as the United States' chief non-monetary contribution to the advancement of sustainable development.

Even in the United States, the refuges have a special leadership role to play in private land conservation. The compatibility principle, of course, finds expression in local planning and zoning ordinances from coast to coast. But, more important than the congruence of legal principles of land use is the similarity of conditions on the refuges with conditions on private land. Many non-Alaskan refuges were already severely degraded when they entered the system. A tradition of intensive habitat manipulation, especially through farming, has erased the historic conditions that signal health and integrity in many refuges. The conditions on refuges are more like those on private property in the same vicinity than other public land systems. Therefore, the techniques that the refuge system develops to restore habitat and sustain wildlife on its non-pristine properties will be applicable to private lands. The refuges remain recognizable to their neighbors, who may be willing to emulate successes they observe in the refuges. 